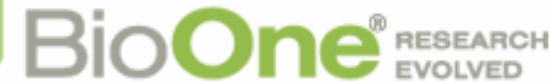

\section{Analysis of Metabolic Activity in Cystic Cells of Triatoma rubrofasciata (Hemiptera: Triatominae) and Its Capacity to Occupy Different Environments}

\author{
Author(s): K.C.C. Alevi , J.G.O. Nascimento , F.F.F. Moreira , J. Jurberg \& \\ M.T.V. Azeredo-Oliveira \\ Source: African Entomology, 24(1):261-264. \\ Published By: Entomological Society of Southern Africa \\ DOI: http://dx.doi.org/10.4001/003.024.0261 \\ URL: http://www.bioone.org/doi/full/10.4001/003.024.0261
}

BioOne (www.bioone.org) is a nonprofit, online aggregation of core research in the biological, ecological, and environmental sciences. BioOne provides a sustainable online platform for over 170 journals and books published by nonprofit societies, associations, museums, institutions, and presses.

Your use of this PDF, the BioOne Web site, and all posted and associated content indicates your acceptance of BioOne's Terms of Use, available at www.bioone.org/page/ terms_of use.

Usage of BioOne content is strictly limited to personal, educational, and non-commercial use. Commercial inquiries or rights and permissions requests should be directed to the individual publisher as copyright holder. 


\title{
Analysis of metabolic activity in cystic cells of Triatoma rubrofasciata (Hemiptera: Triatominae) and its capacity to occupy different environments
}

\author{
K.C.C. Alevi ${ }^{1 *}$, J.G.O. Nascimento ${ }^{1}$, F.F.F. Moreira ${ }^{2}$, \\ J. Jurberg ${ }^{2} \&$ M.T.V. Azeredo-Oliveira ${ }^{1}$ \\ ${ }^{1}$ Laboratory of Cell Biology, Department of Biology, Institute of Biosciences, Humanities and the \\ Exact Sciences, São Paulo State University "Júlio de Mesquita Filho" (UNESP/IBILCE), \\ São Jose do Rio Preto, São Paulo, Brazil \\ ${ }^{2}$ International and National Laboratory of Reference for Triatominae Taxonomy, Oswaldo Cruz \\ Institute (FIOCRUZ), Rio de Janeiro, Rio de Janeiro, Brazil
}

Spermatogenesis is composed of three distinct phases: spermatocytogenesis, which is the proliferation phase; meiosis, which is the division phase; and spermiogenesis, which is the differentiation phase (Johnson et al. 1997).

In insects the spermatogenesis is cystic (Dumser 1980). In cystic spermatogenesis, the meiotic divisions are synchronous within a given cyst (Smith 1916). This phenomenon has been confirmed in the subfamily Triatominae (Silistino-Souza et al. 2011; Alevi et al. 2015).

Cystic spermatogenesis germ cells are contained within a cyst and form a simple layer of cells of mesodermal origin (Dumser 1980). These cells that involve the spermatogonial cysts are termed cystic cells, which undergo polyploidisation events and can display elevated metabolic rate (Cruz-Landim 2001; Schmidt \& Dorn 2004).

The size and number of nucleoli and prenucleolar bodies depend on the functional characteristics of the cells and may reflect metabolic and functional differences (Tavares \& AzeredoOliveira 1997). Therefore, the metabolic rate of cystic cells can be evaluated by characterising the nucleolar pattern.

The nucleolar pattern of 16 species of triatomines was analysed (Tavares \& Azeredo-Oliveira 1997; Severi-Aguiar \& Azeredo-Oliveira 2005; Costa et al. 2008; Mendonça et al. 2010; Bardella et al. 2012; Alevi et al. 2013; Pereira et al. 2015) and most species had only a corpuscle impregnated by silver ions, demonstrating low metabolic activity. However, evaluating the metabolic rate of new species can assist in the understanding of the functional dynamics of cystic cells.

Triatoma rubrofasciata (De Geer) (Hemiptera: Triatominae) is considered of global epidemiological importance, since it presents pantropical distri-

*Author for correspondence. E-mail: kaiochaboli@hotmail.com bution (has been captured in approximately 45 countries (Galvão et al. 2003), highlighting Angola, Congo (Katanga), Guinea (Conakry), Saudi Arabia, Sierra Leone, South Africa, Tanzania (Dujardin et al. 2015) that are on the African continent and was found infected with Trypanosoma cruzi protozoan (Sherlock \& Serafim 1974; Brazil \& Silva 1983), the etiological agent of Chagas disease.

Thus, knowing more about the biology of this vector species is of utmost importance to assist in understanding the ability of $T$. rubrofasciata being able to occupy so many countries with different environmental conditions. Therefore, we describe the nucleolar pattern of the cystic cells of T. rubrofasciata, with emphasis on the analysis of cellular metabolic activity.

Four adult males coming from the National and International Reference Laboratory in Taxonomy of Triatominae, FIOCRUZ, Rio de Janeiro, Brazil, were analysed cytogenetically. Seminiferous tubules were first shredded and squashed on a slide, which was then placed in liquid nitrogen. The preparation was stained by impregnation with silver ions (Howell \& Black 1980).

Based on the analysis of slides it was observed that cystic cells were polyploid and showed many nucleolar marks (Fig. 1A, B), which suggests that the cells of T. rubrofasciata have a high metabolic activity.

We reviewed the literature and grouped all the species that also had cystic cells analysed by means of silver ions (Table 1). From 16 species that have been analysed, only three have similar results to T. rubrofasciata.

The nucleolus is the most prominent structure in a cell nucleus. It is the site of ribosomal RNA (rRNA) transcription, pre-rRNA processing and ribosome subunit assembly (Olson et al. 2002). The analysis of the nucleolar pattern of cystic cells from 


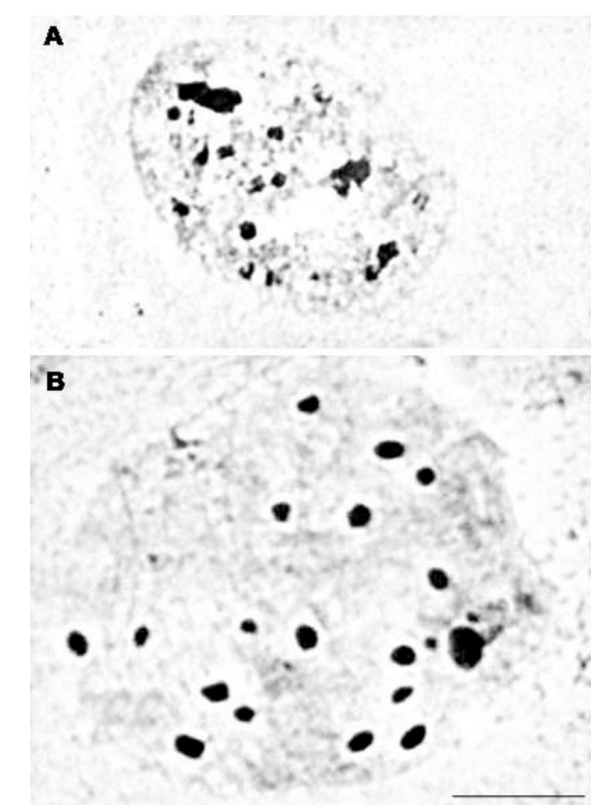

Fig. 1. A, B, Cystic cells of Triatoma rubrofasciata. Note the presence of many nucleolar blocks. Scale bar: $10 \mu \mathrm{m}$.

T. lenti and T. melanocephala allowed Alevi et al. (2013) to report that the cells of T. lenti have a high metabolic activity, since they present many nucleolar markings. In the same perspective, in this study we observed that cystic cells of T. rubrofascita also underwent polyploidisation events and have many nucleolar markings, resulting in high metabolic activity.

The event of polyploidisation present in all cystic cells has been described for cells of other tissues of the triatomines, such as salivary glands (Anhê \& Azeredo-Oliveira 2008; Anhê et al. 2014) and Malpighian tubules (Alvarenga et al. 2011, 2012). This event is critical to the nutritional role that these cells exert on the cells in meiotic division (Schmidt \& Dorn 2004), because it allows certain regions of the genome to be endoreplicated.

We suggest that polyploidy in conjunction with high metabolic activity of T. rubrofascita are important factors for the occupation of 45 countries by the species (Galvão et al. 2003) and assisted in the occupation of home environments. This same characteristic is observed for T. infestans (Bardella et al. 2012), the species of triatomine vectors of most importance in the Americas.

Triatoma rubrofasciata and T. infestans, which live in human households (Silveira \& Rezende 1994) and have many nucleolar marks and wide geographical distribution (Galvão et al. 2003), whereas the endemic species such as T. vandae (Galvão et al. 2003) show only a nucleolar marking. This confirms that the high metabolic activity of T. rubrofasciata, a vector species of great importance, is an extremely important phenomenon for

Table 1. Cytogenetic characteristics of cystic cells of triatomines.

\begin{tabular}{lll}
\hline Species & $\begin{array}{l}\text { Nucleolar markings } \\
\text { in cystic cell }\end{array}$ & References \\
\hline Triatoma brasiliensis & One corpuscle & Tavares \& Azeredo-Oliveira (1997) \\
Triatoma delpontei & One corpuscle & Tavares \& Azeredo-Oliveira (1997) \\
Triatoma infestans & Many corpuscles & Bardella et al. (2012) \\
Triatoma infestans melanosoma & Many corpuscles & Bardella et al. (2012) \\
Triatoma klugi & One corpuscle & Costa et al. (2008) \\
Triatoma lecticularia & One corpuscle & Tavares \& Azeredo-Oliveira (1997) \\
Triatoma lenti & Many corpuscles & Alevi et al. (2013) \\
Triatoma maculata & One corpuscle & Mendonça et al. (2010) \\
Triatoma matogrossensis & One corpuscle & Bardella et al. (2012) \\
Triatoma melanocephala & One corpuscle & Alevi et al. (2013) \\
Triatoma platensis & Many corpuscles & Severi-Aguiar \& Azeredo-Oliveira (2005) \\
Triatoma protracta & One corpuscle & Severi-Aguiar \& Azeredo-Oliveira (2005) \\
Triatoma pseudomaculata & One corpuscle & Mendonça et al. (2010) \\
Triatoma rubrovaria & One corpuscle & Tavares \& Azeredo-Oliveira (1997) \\
Triatoma rubrofasciata & Many corpuscles & This paper \\
Triatoma sordida & Two corpuscles & Tavares \& Azeredo-Oliveira (1997) \\
Triatoma tibiamaculata & One corpuscle & Severi-Aguiar \& Azeredo-Oliveira (2005) \\
Triatoma vandae & One corpuscle & Pereira et al. (2015) \\
Triatoma williami & One corpuscle & Pereira et al. (2015) \\
\hline
\end{tabular}


the occupation of different environments, because it supports all the transcriptional activity necessary for reproduction of species in new environments.

Thus we suggest that cystic cells of T. rubrofasciata have high metabolic activity and relate this phenomenon to the vectorial capacity of these insects to inhabit different countries.

\section{REFERENCES}

ALEVI, K.C.C., CASTRO, N.F.C., OLIVEIRA, J., ROSA, J.A. \& AZEREDO-OLIVEIRA, M.T.V. 2015. Cystic spermatogenesis in three species of the prolixus complex (Hemiptera: Triatominae). Italian Journal of Zoology 82: $172-178$.

ALEVI, K.C.C., MENDONÇA, P.P., PEREIRA, N.P., ROSA, J.A. \& AZEREDO-OLIVEIRA, M.T.V. 2013. Análise das regióes organizadoras nucleolares e da atividade nucleolar em Triatoma melanocephala e $T$. lenti, importantes vetores da doença de Chagas. Revista de Ciências Farmacêuticas Básica e Aplicada 34: 417-421.

ALVARENGA, E.M., MONDIN, M., MARTINS, J.A., RODRIGUES, V.L.C.C., VIDAL, B.C., RINCONES, J., CARAZZOLLE, M.F., ANDRADE, L.M. \& MELLO, M.L.S. 2011. Spatial distribution of AT- and GC-rich DNA within interphase cell nuclei of Triatoma infestans Klug. Micron 42: 568-578.

ALVARENGA, E.M., MONDIN, M., RODRIGUES, V.L.C.C., ANDRADE, L.M., VIDAL, B.C. \& MELLO, M.L.S. 2012. Contribution of AT-, GC-, and methylated cytidine-rich DNA to chromatin composition in Malpighian tubule cell nuclei of Panstrongylus megistus (Hemiptera, Reduviidae). Acta Histochemica 114: 665-672.

ANHÊ, A.C.B. \& AZEREDO-OLIVEIRA, M.T.V. 2008. Cytochemical characterization of Triatoma infestans and Panstrongylus megistus salivary gland cells (Hemiptera, Reduviidae, Triatominae). Micron 39: 1126-1133.

ANHÊ, A.C.B.M., LIMA-OLIVEIRA, A.P.M. \& AZEREDO-OLIVEIRA, M.T.V. 2014. Cytochemical study of Rhodnius neglectus and Rhodnius prolixus salivary gland cells (Hemiptera, Triatominae). Iheringia 104: 399-403.

BARDELLA, V.B., SOUZA, R.S., SAN MARTIN, J.A., ANDRADE, C.G., VANZELA, A.L. \& AZEREDOOLIVEIRA, M.T.V. 2012. Cytogenetic characterization reveals differences in nuclear organization of cystic cells among Brazilian species of Triatoma (Heteroptera, Reduviidae). Cell Biology International 36: 1287-1291.

BRASIL, R.P. \& SILVA, A.R. 1983. Triatomine vectors of Trypanosoma cruzi-like trypanosomes in urban areas of São Luiz, Maranhão, Brasil. Transaction of the Royal Society of Tropical Medicine and Hygiene 77: 568

COSTA, L.C., AZEREDO-OLIVEIRA, M.T.V. \& TARTAROTTI, E. 2008. Spermatogenesis and nucleo-

\section{ACKNOWLEDGEMENTS}

This work was supported by the Fundação de Amparo à Pesquisa do Estado de São Paulo (FAPESP) (Process No. 2013/19764-0), Fundação de Apoio à Pesquisa e Extensão e São José do Rio Preto (FAPERP) (Process No. 60/2015) and the Conselho Nacional de Desenvolvimento Científico e Tecnológico (CNPq).

lar activity in Triatoma klugi (Triatominae, Heteroptera). Genetics and Molecular Biology 31: 438-444.

CRUZ-LANDIM, C. 2001. Organization of the cysts in bee (Hymenoptera, Apidae) testis: number of spermatozoa per cyst. Iheringia 91: 183-189.

DUJARDIN, J.P., LAM, T.X., KHOA, P.T. \& SCHOFIELD, C.J. 2015. The rising importance of Triatoma rubrofasciata. Memórias do Instituto Oswaldo Cruz 110: 319-323.

DUMSER, J.B. 1980. The regulation of spermatogenesis in insects. Annual Review of Entomology 25: 341-369.

GALVÃO, C., CARCAVALLO, R.U., ROCHA, D.S. \& JURBERG, J. 2003. A checklist of the current valid species of the subfamily Triatominae Jeannel, 1919 (Hemiptera, Reduviidae) and their geographical distribution, with nomenclatural and taxonomic notes. Zootaxa 202: 1-36.

HOWELL, W.M. \& BLACK, D.A. 1980. Controlled silverstaining of nucleolus organizer regions with a protective colloidal developer: a 1-step method. Experientia 36: 1014-1015.

JOHNSON, L., BLANCHARD, T.L., VARNER, D.D. \& SCRUTCHFIELD, W.L. 1997. Factors affecting spermatogenesis in the stallion. Theriogenology 48: 1199-1216.

MENDONÇA, P.P. 2010. Comparative study of the cytogenetic and molecular characteristics of Triatoma maculata and T. pseudomaculata (Heteroptera, Triatominae), Genetics and Molecular Research 9: 434.

OLSON, M.O., HINGORANI, K. \& SZEBENI, A. 2002. Conventional and nonconventional roles of the nucleolus. International Review of Cytology 219: 199-266.

PEREIRA, N.P., ALEVI, K.C.C., MENDONÇA, P.P. \& AZEREDO-OLIVEIRA, M.T.V. 2015. Spermatogenesis and nucleolar behavior in Triatoma vandae and T. williami (Hemiptera, Triatominae). Genetics and Molecular Research 14: 12145-12151.

SCHMIDT, E.D. \& DORN, A. 2004. Structural polarity and dynamics of male germ line stem cells in the milkweed bug (Oncopeltus fasciatus). Cell and Tissue Research 318: 383-294.

SEVERI-AGUIAR, G.D.C. \& AZEREDO-OLIVEIRA, M.T.V. 2005. Cytogenetic study on three species of the genus Triatoma (Heteroptera: Reduviidae) with emphasis on nucleolar organizer regions. Caryologia 58: 293-299.

SHERLOCK, I.A. \& SERAFIM, E.M. 1974. Fauna Triatominae do Estado da Bahia, Brasil. VI. Preva- 
lência geográfica da infecção dos triatomíneos por T. cruzi. Revista da Sociedade Brasileira de Medicina Tropical 8: 129-142.

SILISTINO-SOUZA, R. 2011. Chagas disease and triatomine biology (Heteroptera, Triatominae), with emphasis on aspects of spermatogenesis. Genetics and Molecular Research 10: 1753.

SILVEIRA, A.C. \& REZENDE, D.F. 1994. Epidemiologia e controle da transmissão vetorial da doença de Cha- gas no Brasil. Revista da Sociedade Brasileira de Medicina Tropical 27: 11-22.

SMITH, E.A. 1916. Spermatogenesis of the dragon-fly Sympetrum semicinctum (Say) with remarks upon Libellula basalis. Biological Bulletin 31: 269-302.

TAVARES, M.G. \& AZEREDO-OLIVEIRA, M.J.V. 1997. Pattern of nucleolar activity during spermatogenesis in triatomines (Heteroptera: Reduviidae) as analysed by silver staining. Cytobios 89: 93-103. 